\title{
Does Consumer Gender Influence The Relationship Between Consumer Loyalty And Its Antecedents?
}

Valentina Stan, Ph.D., Professor, ESSCA School of Management, France

\begin{abstract}
A retailer can improve consumer loyalty to a store by identifying and implementing a suitable marketing strategy, which must start with proper understanding of the factors that influence shoppers' choice behavior. Several empirical studies on buying behavior have pointed out that customer demographics may be related to store loyalty. Regarding gender, even if this variable is often perceived as a main predictor of differential outcomes in social psychology literature, it is not yet clear how these differences impact customer loyalty and the relationship between consumer loyalty and its antecedents. The findings of this study demonstrate that women are more loyal to store than men. In addition to this, it can be noted that gender does not moderate any of the relationships between loyalty and its antecedents.
\end{abstract}

Keywords: Gender; Customer Loyalty; Customer Satisfaction; Store Image; Perceived Value

\section{INTRODUCTION}

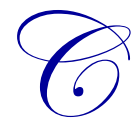

ustomer loyalty is crucial in customer relationship management (Melnyk et al. 2009) and is "the raison d'être of omnipresent loyalty programs" (Melnyk et al. 2009; see also Kivetz and Simonson 2002, 2003; Van Heerde and Bijmolt, 2005; Yuping and Yang, 2009). In order to maximize customers' loyalty, retailers need to know what factors influence it and their relative importance. For several decades marketing literature has focused on satisfaction, perceived value, quality and image as success factors influencing consumers' loyalty (Sirgy, 1985; Fornell, 1992; Oliver, 1999; Grewal et al. 2004). However, understanding the influence of gender differences in these success factors would enable managers to allocate resources more efficiently. Even if gender is often perceived as a main predictor of differential outcomes in social psychology literature (Helgesen and Nesset, 2010), it is not yet clear how these differences impact customer loyalty. As highlighted by Melnyk et al. (2009) "this is surprising because if male and female loyalties differ, men and women might require a different selling approach, have different levels of customer value, and respond differently to loyalty programs and other actions aimed at enhancing customer loyalty".

Empirical research shows that men and women could have different attitudinal and behavioral orientations in their buying behavior (Homburg and Giering, 2001; Noble et al. 2006; Helgesen and Nesset, 2010). The study conducted by Melnyk et al. (2009) showed that whereas female customers are relatively more loyal to individuals, male customers are relatively more loyal to companies. The authors highlighted that men are collectively more interdependent and associate firms and their offerings with collective entities. Nevertheless, this finding contradicts other research that includes gender as a control variable (Frank et al. (2014). Such research proved that the level of repurchase intent is higher for women than for men (Mittal and Kamakura, 2001; Dimitriades, 2006) or there is no significant difference by gender (McGoldrick and Andre, 1997; Bendall-Lyon and Powers, 2002; Kim and Yoon, 2004; Bell et al. 2005).

Despite the importance of customer loyalty on the one hand and gender differences on the other hand, few empirical studies about the impact on gender differences on the relationship between consumer loyalty and its 
antecedents have been conducted in marketing literature and the results are mixed. The study conducted by Mittal and Kamakura (2001) showed that customer satisfaction is a more important driver of repurchase intent for men than for women. Another study carried out by Helgesen et al. 2010 did not find that gender is a moderator of the relationship between image, satisfaction and loyalty. Recently, the research conducted by Frank et al. (2014) has not found any gender difference in the influence of customer satisfaction on repurchase intent. The authors also showed that perceived value has a weaker effect on repurchase intent for women than for men but public brand image more strongly influences repurchase intent for women than for men.

In such a context, the aim of this study is to answer the questions:

- Are women more loyal consumers to the store than men?

- Does consumer gender influence the relationship between consumer loyalty and its antecedents?

Concerning the antecedents of customer loyalty to the store, this study focuses on satisfaction, perceived value and store image.

The layout of the paper begins with the conceptual framework and hypothesis development. Next, the methodology is described and the study's findings are subsequently presented. The final section presents discussion and conclusion.

\section{CONCEPTUAL FRAMEWORK AND HYPOTHESIS DEVELOPMENT}

According to Melnyk et al. (2009, p. 82) “...common elements among many of the loyalty definitions are that there is a relationship of some sort (i.e., ranging from very shallow to very strong) between an actor and another entity and that the actor displays behavioral or psychological allegiance to that entity in the presence of alternative entities." Store loyalty can be viewed as a construct containing a tripartite attitudinal component (cognitive, affective and conative) and strongly connected behavioural component (repeat patronage-retention) (Evanschitzky and Wunderlich, 2006; Helgesen et al. 2010). Researchers and managers point out that small changes in loyalty and retention can produce disproportionately substantial changes in profitability (Reichheld, 1993; Reichheld et al. 2000).

In the meantime, researchers have studied many levers of customer loyalty to stores, companies, and brands (see Dick and Basu 1994; Oliver 1999; Johnson et al. 2006; Stan and Caemmerer, 2015). In marketing literature, customer satisfaction with products and services is the most commonly accepted antecedent of customer loyalty. According to Fornell (2002, p. 4) "satisfied customers can be viewed as economic assets that yield future cash flows." Satisfaction is based on a comparison between the perceived and expected store performance. Thus, consumers with positive experiences continue visiting the store. Researchers pointed out that there is a difference between customer satisfaction with tangible products and with service experiences (Dimitriades, 2006). This difference can be explained by the inherent intangibility and perishability of services, as well as the incapacity to separate production and consumption (Veloutsou et al. 2005; Dimitriades, 2006). Empirical studies have proved the relationship between customer satisfaction, customer loyalty and company's outcomes such as market share and profitability (Fornell, 1992; Rust et al. 1995; Fornell et al. 2006). In recent years, large-scale national barometers such as the Swedish Customer Satisfaction Index (Fornell, 1992), the American Customer Satisfaction Index (Fornell et al. 1996) and the European Customer Satisfaction Index (Cassel and Eklof, 2001) have been developed.

Another determinant of customer loyalty is perceived value of products and services which is defined as perceived quality compared to the price (Fornell et al. 2005). In addition, merchandise value has been associated to the pleasure resulting from obtaining a good deal (Grewal et al. 1998). In retail markets, previous studies also use the "give-get" notion of value (Zeithaml, 1988; Dodds et al. 1991; Grewal et al. 1998; Cronin et al. 2000; Baker et al. 2002). Chaudhuri and Ligas (2009) suggest that one of the consequences of merchandise value would seem to be a simple interest in returning to the store (with a view to regaining such value). As perceived value impacts consumer satisfaction, its effect on loyalty is mediated by satisfaction (Fornell et al. 2005). Given the importance of 
price in repurchase decisions, perceived value also influences loyalty directly (Johnson et al. 2001; Ngobo, 2004; Frank et al. 2014).

Image concept is viewed as being crucial for attracting and retaining consumers (Bloemer and de Ruyter, 1998; Pan and Zinkhan, 2006; Helgesen et al. 2010). Store image is generally defined as «...the way in which the store is perceived by shoppers» (Pan and Zinkhan, 2006, p. 231). More recently, Martenson (2007) showed that store image was mainly explained by consumers' perception of the store as a brand (e.g. quality of relationship with consumers, neatness of the store, product assortment). Previous studies have shown that store image is a predictor of satisfaction (Boloemer and de Ruyter 1998; Stan, 2014), of perceived value (Grewal et al. 2004; Stan, 2014) and a predictor of loyalty (Bellenger et al. 1976; Sirgy, 1985; Stan, 2014).

The model depicted in figure 1 offers a viable representation of consumer loyalty to store and guides our study. Taking into account the strong theoretical and empirical support for the relationships in the model, we do not propose a specific hypothesis for each relationship. Instead, this model serves as a basis for testing gender related hypotheses.

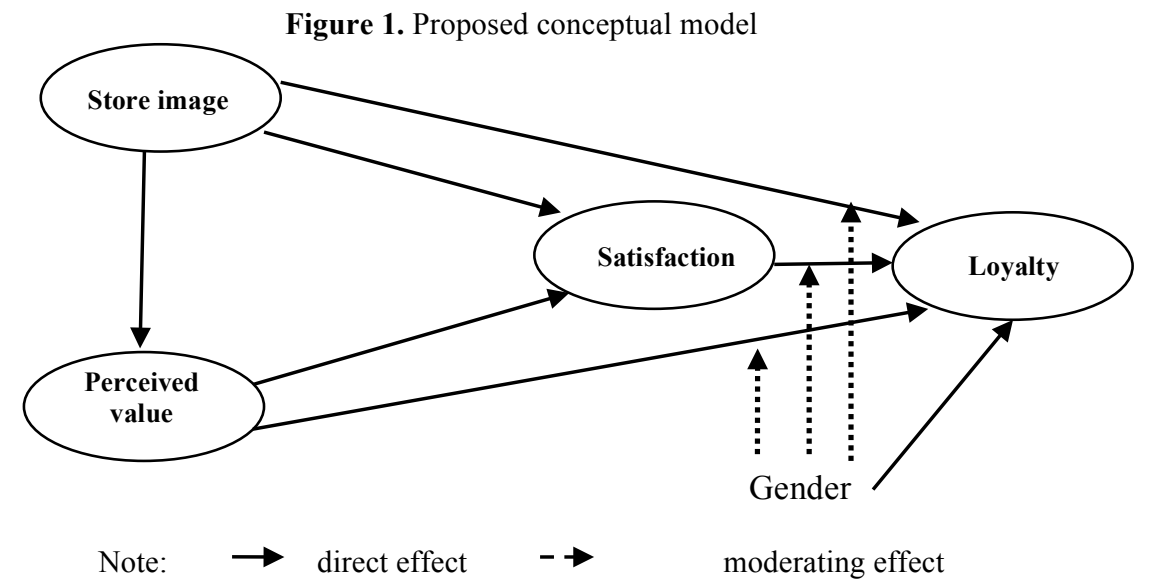

The direct and moderating effect are assumed to be linear here.

\section{Effects of Gender}

Several empirical studies on buying behavior have pointed out that customer demographics may be related to store loyalty (Pan and Zinkhan, 2006). Regarding gender, some studies have proved the existence of significant differences between men and women relating to experience and expression of emotion (Stearns, 1992; Lewis, 2000) and in information processing, with men being more analytical, while women tend to be more subjective (Allinson and Hayes, 1996; McColl-Kennedy et al. 2003). According to Putrevu (2001), differences between women and men derived partially from biological make up and partially from socialization experiences. Babakus and Yavas (2008, p. 976) highlighted that men are "primarily guided by societal norms that require control, mastery and self-efficacy to pursue self-centered goals," while women are "guided by concerns for self and others and emphasize affiliation and harmonious relationships with others." Therefore, women customers are expected to be more relationshiporiented and loyal than men customers (Ndubisi, 2006; Pan and Zinkhan, 2006).

H1: Women are more loyal store customers than men

As we highlighted above, the second research question of this study concerns the moderating effect of gender of the relationship between consumer loyalty and its antecedents.

Regarding customer satisfaction, Homburg and Giering (2001) carried out a study for a German car manufacturer and found that satisfaction with the products has a significant effect on the intention to repurchase for men but not for women. This result is important for managers because a man's decision to purchase the next car at the same care dealer is strongly impacted by his satisfaction with the functionality of the product itself. 
The authors also showed that satisfaction with sales process impacted a woman's buying decision. Another study conducted by Mittal and Kamakura (2001) in the U.S. automotive industry found a stronger effect of customer satisfaction on men's than women's repurchase behavior. Frank et al. 2014 explained this difference on the basis of gender schemata theory: "men are raised to fulfill more instrumental roles, whereas women are raised to fulfill more expressive roles". Using this theoretical foundation, Campbell (1997) pointed out that men consider shopping as a needs-driven process and pay attention to product or service, while women consider shopping as a recreational experience with social and hedonic benefits beyond the satisfaction resulting from the product or service itself. Upon formation the repurchase intentions, men can therefore count more on satisfaction with products and services, while women can count more on other benefits of the shopping experience (Frank et al. 2014). In accordance with previous research, we propose:

H2: The positive effect of customer satisfaction on customer loyalty is weaker for women than for men.

Prior research has showed that higher perceived value is reached when the consumer obtains higher perceived quality for the same price or the same perceived quality for a lower price. As highlighted by Frank et al. (2014, p. 175) "gender differences in how perceived value affects repurchase intent are thus caused by gender differences in the importance of quality or price". Noble et al. (2006) suggest that women are attracted to exclusivity and uniqueness as attributes of products and services. Women may be willing to pay higher prices to get these attributes given that need for uniqueness positively affects willingness to pay (Tian et al. 2001). Research also pointed out that women pay more than men to maintain harmonious relationships with salespeople and obtain products which are certain to please other people (Gelfand et al. 2006; Cron et al. 2009). Moutinho et al. 1996 argued that price is interpreted as an indicator of quality much more by women than men. Thus, women tend more to doubt and avoid very low-priced products (Frank et al. 2014).

Other studies pointed out that compared with women, men are more task-oriented and place more importance on efficiency and achievement than do women (Eagly, 1987; Meyers-Levy, 1988; Schwartz and RubelLifschitz, 2005, 2009). Men thus compromise less on lower prices (Gelfand et al. 2006; Stuhlmacher and Walters, 1999) and higher product quality (Iacobucci and Ostrom, 1993; Chiu, 2002). To conclude, the psychological literature of gender differences provides reasons to suppose that men focus more than women on higher quality and lower prices in repurchase decisions. Therefore, we put forward the following hypothesis:

H3: The positive effect of perceived value on customer loyalty is weaker for women than for men.

A favorable image expresses trust in product choices and provides social demonstrance, that is, impressing other consumers (Ball et al. 2004; Türky1lmaz and Özkan, 2007; Fischer et al. 2010; Frank et al. 2014). Store image reflects public trust in the shop, diminishes perceived risk, and is sensitive to product safety concerns (Ball et al. 2004; Fischer et al. 2010). Marketing and psychology literature suggests that women pay more attention than to men to trust (Ndubisi, 2006; Shemwell and Cronin, 1995), security (Schwartz and Rubel-Lifschitz, 2005, 2009) as well as risk reduction (Garbarino and Strahilevitz, 2004). According to Lawrence et al. (2006) and Moutinho et al. (1996), the social confidence of women is more dependent on their self-image and on how they impress others. Consistent consumption of the same brand with a favorable image allows consumers to transfer positive brand associations to themselves (Ball et al. 2004; Escalas and Bettman, 2005; Türkyılmaz and Özkan, 2007). In line with the above we propose the following hypothesis:

H4: The positive effect of store image on customer loyalty is stronger for women than for men.

\section{METHODOLOGY}

Testing of the research model and hypotheses was carried out thanks to data collected in conjunction with a major American retailer. The sample was randomly generated using the list for the retailer's loyalty program. A total of 3049 respondents participated in the current study. To test our hypotheses we designed the survey questionnaire by using scales adapted from marketing literature. The items, except for "loyalty," were ranked on a scale of 1 to 10 with 1 representing "strongly disagree" and conversely 10 "strongly agree;" loyalty was measured on a scale from 1 
to 5 ( 1 = "strongly disagree" and $5=$ "strongly agree"). Table 1 presents the scales this study used. The survey was mailed to individual consumer households with the specific instructions that it be filled in by the member of each household in charge of doing the grocery shopping. The sample's main attributes are thus:

\section{Gender:}

men: $48 \%$

women: $52 \%$

Age:
$[18 ; 25]: 3 \%$
$[25 ; 45]: 39 \%$
$[45 ; 65]: 49 \%$
$[65 ; 85]: 9 \%$

Table 1. Scales used in the study

Constructs and Items

Store image (adapted from Mazursky and Jacoby, 1986; Baker et al. 1994)

You are familiar with them and understand what they are about. (Image1)

They have different services that other discount retail stores do not have. (Image 2)

They are a popular discount retail store. (Image 3)

They feel like a friend. (Image 4)

Perceived value (adapted from Sweeney and Soutar, 2001)

This store offers value for money. (Value 1)

This store provides a good service for the price. (Value 2)

Customer Satisfaction (adapted from Oliver, 1981; Mittal and Kamakura, 2001)

Overall Satisfaction (Satisf 1)

Meet Expectations (Satisf 2)

Customer loyalty (adapted from Mittal et al. 1998; Maxham and Netemeyer, 2002)

Six months from now, how likely are you to still be shopping at $<>$ ? (Loyalty 1 )

How likely would you be to recommend $<\quad>$ to friends and colleagues? (Loyalty 2 )

\section{FINDINGS}

To test the model depicted in figure 1 we used the Partial Least Squares (PLS) approach (Wold, 1966; Chin, 1998a, b; Tenenhaus et al. 2005) with XLSTAT 2014 software. The measurement model was tested by assessing individual item reliability, construct reliability and unidimensionality, convergent and discriminant validity (Bagozzi, 1981). The relationships between the manifest variables (measures) and their latent variables are supposed to be reflective here.

The structural model was tested by estimating the path coefficients between the constructs and the $\mathrm{R}^{2}$ for the endogenous variables. 


\section{Measurement Model}

Individual Item Reliability

This criterion is assessed with the factor loadings. The recommended values for this indicator should be above 0.7 (Carmines and Zeller, 1979). The following table shows that all factor loadings are higher than 0.7.

Table 2. Factor loadings

\begin{tabular}{lccc}
\hline \multicolumn{1}{c}{ Latent variable } & Total sample $(\mathbf{n = 3 0 4 9 )}$ & Men sample $(\mathbf{n = 1 4 8 0})$ & Women sample $(\mathbf{n}=\mathbf{1 5 6 9 )}$ \\
\hline Satisfaction & & & 0.959 \\
\hline Satisf 1 & 0.964 & 0.971 & 0.964 \\
Satisf 2 & 0.966 & 0.969 & 0.817 \\
\hline Image & & & 0.794 \\
\hline Image 1 & 0.802 & 0.782 & 0.772 \\
Image 2 & 0.785 & 0.769 & 0.847 \\
Image 3 & 0.753 & 0.724 & 0.936 \\
Image 4 & 0.830 & 0.806 & 0.893 \\
\hline Value & & & 0.925 \\
\hline Value 1 & 0.932 & 0.899 & 0.924 \\
Value 2 & 0.896 & & 0.944 \\
\hline Loyalty & & 0.896 & 0.937 \\
Loyalty 1 & 0.912 & & \\
\hline
\end{tabular}

Construct Reliability and Unidimensionality

In order to verify the construct reliability of each latent variable we use Cronbach's $\alpha$. As shown in the following table all $\alpha$ values meet the reliability analysis of $\alpha>0.75$ (Tenenhaus et al. 2005) and all constructs are unidimensional.

Table 3. Reliability and Unidimensionality

\begin{tabular}{|c|c|c|c|c|c|c|c|c|c|}
\hline \multirow[b]{2}{*}{$\begin{array}{c}\text { Latent } \\
\text { variable }\end{array}$} & \multicolumn{3}{|c|}{ Total sample } & \multicolumn{3}{|c|}{ Men Sample } & \multicolumn{3}{|c|}{ Women Sample } \\
\hline & $\begin{array}{c}\text { Cronbach's } \\
\alpha \\
\end{array}$ & $\begin{array}{c}\text { First } \\
\text { Eigenvalue }\end{array}$ & $\begin{array}{c}\text { Second } \\
\text { Eigenvalue }\end{array}$ & $\begin{array}{c}\text { Cronbach's } \\
\alpha \\
\end{array}$ & $\begin{array}{c}\text { First } \\
\text { Eigenvalue }\end{array}$ & $\begin{array}{c}\text { Second } \\
\text { Eigenvalue }\end{array}$ & $\begin{array}{c}\text { Cronbach's } \\
\alpha \\
\end{array}$ & $\begin{array}{c}\text { First } \\
\text { Eigenvalue }\end{array}$ & $\begin{array}{c}\text { Second } \\
\text { Eigenvalue }\end{array}$ \\
\hline Image & 0.803 & 2.517 & 0.703 & 0.773 & 2.380 & 0.779 & 0.823 & 2.612 & 0.651 \\
\hline Value & 0.805 & 1.674 & 0.326 & 0.799 & 1.666 & 0.334 & 0.809 & 1.679 & 0.321 \\
\hline Satisfaction & 0.927 & 1.863 & 0.137 & 0.937 & 1.881 & 0.119 & 0.919 & 1.850 & 0.150 \\
\hline Loyalty & 0.836 & 1.718 & 0.282 & 0.812 & 1.683 & 0.317 & 0.854 & 1.745 & 0.255 \\
\hline
\end{tabular}

Convergent validity of the constructs was fulfilled as AVE values (Average Variance Extracted) were greater than 0.5 (Fornell and Larcker, 1981). The following table shows that all AVE exceed 0.50, confirming that all constructs demonstrate satisfactory convergent validity (Chin, 1998b).

Table 4. Average Variances Extracted

\begin{tabular}{lccc}
\hline \multicolumn{1}{c}{ Latent variable } & Total Sample & Men Sample & Women Sample \\
\hline Image & 0.629 & 0.594 & 0.653 \\
Value & 0.835 & 0.832 & 0.838 \\
Satisfaction & 0.932 & 0.940 & 0.925 \\
Loyalty & 0.858 & 0.840 & 0.872 \\
\hline
\end{tabular}

The Discriminant Validity of constructs was assessed by comparing AVE values to squared correlations between the constructs. This criterion is satisfied when the AVE values (the matrix diagonal) are superior to squared correlations between the constructs (Fornell and Larker, 1981). Table 4 shows that this condition has been satisfied. 
Table 5. Discriminant Validity

\begin{tabular}{|c|c|c|c|c|c|c|c|c|c|c|c|c|}
\hline & \multicolumn{4}{|c|}{ Total sample } & \multicolumn{4}{|c|}{ Men sample } & \multicolumn{4}{|c|}{ Women sample } \\
\hline & Image & Value & $\begin{array}{c}\text { Satis- } \\
\text { faction }\end{array}$ & Loyalty & Image & Value & $\begin{array}{c}\text { Satis- } \\
\text { faction }\end{array}$ & Loyalty & Image & Value & $\begin{array}{c}\text { Satis- } \\
\text { faction }\end{array}$ & Loyalty \\
\hline Image & 0.629 & 0.452 & 0.424 & 0.347 & 0.594 & 0.477 & 0.434 & 0.330 & 0.653 & 0.436 & 0.415 & 0.354 \\
\hline Value & & 0.835 & 0.409 & 0.320 & & 0.832 & 0.386 & 0.290 & & 0.838 & 0.428 & 0.345 \\
\hline Satisfaction & & & 0.932 & 0.449 & & & 0.940 & 0.436 & & & 0.925 & 0.459 \\
\hline Loyalty & & & & 0.858 & & & & 0.840 & & & & 0.872 \\
\hline
\end{tabular}

\section{Structural Model}

The global index, Goodness of Fit (GoF, Tenenhaus et al., 2005), shows very good results for all samples, which demonstrate that the overall model fit:

- total sample: 0.615

- $\quad$ men's sample: 0.607

- $\quad$ women's sample: 0.622 .

Table 6. Results of Structural Model

\begin{tabular}{|c|c|c|c|c|c|c|c|c|c|c|}
\hline \multirow{2}{*}{$\begin{array}{l}\text { Dependent } \\
\text { Variables }\end{array}$} & \multirow{2}{*}{$\begin{array}{l}\text { Explanatory } \\
\text { Variable }\end{array}$} & \multicolumn{3}{|c|}{ Total sample } & \multicolumn{3}{|c|}{ Men sample } & \multicolumn{3}{|c|}{ Women sample } \\
\hline & & $\mathbf{R}^{2}$ & $\begin{array}{l}\text { Path } \\
\text { coef }\end{array}$ & $\begin{array}{c}\text { p- } \\
\text { value }\end{array}$ & $\mathbf{R}^{2}$ & $\begin{array}{l}\text { Path } \\
\text { coef }\end{array}$ & $\begin{array}{c}\text { p- } \\
\text { value }\end{array}$ & $\mathbf{R}^{2}$ & $\begin{array}{l}\text { Path } \\
\text { coef }\end{array}$ & $\begin{array}{c}\text { p- } \\
\text { value }\end{array}$ \\
\hline \multirow[t]{4}{*}{ Loyalty } & Satisfaction & \multirow{4}{*}{0.503} & 0.446 & 0.000 & \multirow{4}{*}{0.478} & 0.461 & 0.000 & \multirow{4}{*}{0.515} & 0.438 & 0.000 \\
\hline & Store Image & & 0.195 & 0.000 & & 0.184 & 0.000 & & 0.203 & 0.000 \\
\hline & Value & & 0.148 & 0.000 & & 0.125 & 0.000 & & 0.167 & 0.000 \\
\hline & Gender & & 0.052 & 0.000 & & & & & & \\
\hline \multirow[t]{2}{*}{ Satisfaction } & Store Image & 0.498 & 0.404 & 0.000 & 0.487 & 0.440 & 0.000 & 0.508 & 0.377 & 0.000 \\
\hline & Value & & 0.368 & 0.000 & & 0.317 & 0.000 & & 0.405 & 0.000 \\
\hline Value & Store Image & 0.452 & 0.672 & 0.000 & 0.477 & 0.690 & 0.000 & 0.436 & 0.660 & 0.000 \\
\hline
\end{tabular}

The predictive value of the endogenous variables was assessed using the $\mathrm{R}^{2}$ value for the dependent variables, which determine the amount of variance explained by the model. Our results indicate that the predictors explain substantial amounts of variance in the endogenous variables for all samples. Concerning loyalty, the theoretical model explains approximately $50 \%$ of the variance, which demonstrates a very satisfactory predictability. The results also show that all relationships are significant ( $\mathrm{p}$-value $=0$ ) which validate the proposed model as a feasible platform for testing gender-related hypotheses.

\section{Tests of Research Hypotheses}

As indicate in table 6, the first hypothesis (H1: women are more loyal customer to the store than men) is supported (path coef $=0.052 ; \mathrm{p}$-value $=0$ ). Furthermore, table 6 shows that the total effect of interaction satisfaction on loyalty is 0.438 and 0.461 for the women's and men's samples respectively. Thereafter, the total effect of perceived value on loyalty for women consumers is 0.167 and 0.125 for men, and the total effect of store image on loyalty for women consumers is 0.203 and 0.184 for men. In going beyond these observations and formally testing $\mathrm{H} 2, \mathrm{H} 3$ and $\mathrm{H} 4$ hypotheses we used multi-group comparison methods in the framework of PLS Path Modeling (Chin and Dibbern, 2005). Here we used XLstat software with a permutation test. The next table shows that the hypotheses H2, H3 and H4 are not supported (p-value > 0.05).

Table 7. Results of Multi-group Permutation Test

\begin{tabular}{lcc}
\hline \multicolumn{1}{c}{ Latent variables } & Difference & p-value \\
\hline Image $\rightarrow$ Loyalty & 0.019 & 0.756 \\
Value $\rightarrow$ Loyalty & 0.042 & 0.318 \\
Satisfaction $\rightarrow$ Loyalty & 0.023 & 0.672 \\
\hline
\end{tabular}




\section{DISCUSSION AND CONCLUSION}

The contemporary marketing literature, switching from a transaction orientation to a relationship orientation (Berry, 1995; Grönroos, 1995, Morgan and Hunt, 1994), allows that gaining and retaining customer loyalty as the final objective may be more important than meeting customer satisfaction (Augustin and Sing, 2005; Evanschitzky and Wunderlich, 2006). A retailer can improve consumer loyalty to a store by identifying and implementing a suitable marketing strategy, which must start with proper understanding of the factors that influence shoppers' choice behavior (Pan and Zinkhan, 2006). Our study indicates that customer satisfaction has the strongest direct impact on loyalty, followed by store image and perceived value and these findings are supported by all samples. Thus, increasing customer satisfaction diminishes the risk and volatility associated with future net cash flows (Fornell et al. 2006) because satisfied customers are less interested in competitor's efforts.

Our results also show that store image remains more important than perceived value in the formation of customer loyalty, though we can note that store image also has a positive impact on satisfaction and perceived value. Therefore, an increase in store image resulted in an indirect increase in store loyalty via store satisfaction and value but also in a direct increase. Accordingly, store image is crucial for the retailers' marketing strategy. As highlighted by Ball et al. (2006), Türkyılmaz and Özkan (2007) a positive store image arises from social contributions, reliability, professionalism, and innovation but also from communicating these advantages through advertising.

The perceived value - loyalty relationship is another important factor for retailers in the long term. Perceived value has a direct impact on loyalty as well as an indirect impact via store satisfaction. According to Chaudhuri and Ligas (2009, p. 408) "an acceptable match between an individual's expectations of price and quality and a store's offerings on these same features result in a willingness or interest in obtaining the same value at the store in the future". There are consumers who estimate perceived value based on economic reasons and who will return to a store that offers good quality at a fair price. Yet, consumers could be motivated to carry out inter-store comparison (Krishnan et al. 2006) and obtain an assessment of the relative value of the store compared to others.

The findings also demonstrate that women are more loyal to store than men. As suggested by Pan and Zinkhan (2006), "gender is the only successful demographic variable, which suggests that women tend to be more frequent shoppers than men". On the other hand, women are prone to interdependent self-construal and the objective is to develop self-defining relations to maintain a connection with others via interpersonal affiliations, affiliations to groups, and to a community (Cross and Madson, 1997; Noble et al. 2006). On the contrary, men tend to rely on independent self-construal and thus are less concerned with these types of affiliations (Cross and Madson, 1997; Noble et al. 2006). As the retailer who participated in the current study, it is located in a residential community, and this could explain that women are more loyal to the store, thanks to a sense of important affiliation and connectedness (Noble et al. 2006). This finding is important for retailer strategy and suggests that the retailer should focus on the role of the store in the community when interacting with women (via advertising or in-store interactions).

In addition to this, it can be noted that gender does not moderate any of the relationships between loyalty and its antecedents. Indeed, the path coefficients of the relationships between the 3 antecedents and loyalty are not significant different between women and men sample. Concerning the relationship between customer satisfaction and loyalty, our findings are in line with previous research such Helgesen et al. 2010, Frank et al. (2014). As in Helgesen et al. 2010, our study did not find that gender moderates the relationship between store image and loyalty. However, contrary to the study carried out by Frank et al. (2014), our results show that gender does not serve as a moderator of the relationship between value and loyalty. A possible explanation of these results could be that retail stores offer mainly low-involvement products. Most products of the retailer stores are purchased with lower levels of affection. Nevertheless, we can note that some products offered by the retailer might be high-involvement products as well.

As with all empirical research, this study has several limitations. First, we considered data from one particular point in time only. However, proceeding in this way, we assume there is no time lag between a consumer's feeling of being satisfied and the behavioral consequences. Therefore, it would be interesting to carry out a longitudinal study. Second, we only used linear relationships between loyalty and its antecedents. 
Nevertheless, several studies find that these relationships are non-linear (Anderson and Mittal, 2000; Mittal and Kamakura, 2001) and that further research is needed. Finally, our study focused on one demographic variable gender. It would by interesting for the retailer's strategy to analyze the moderating effect of other demographic variables such as age, income, education.

\section{AUTHOR INFORMATION}

Valentina Stan, Ph.D., Professor of Marketing, ESSCA School of Management, 55 Quai Alphonse Le Gallo, 92513 Boulogne Billancourt Cedex, France. Dr. Stan received her Ph.D from CNAM Paris, France. Her research interests include customer satisfaction and loyalty, Structural Equation Modelling. E-mail: valentina.stan@essca.fr

\section{REFERENCES}

Allinson, C.N., \& Hayes, J. (1996). The cognitive style index: A measure of intuition analysis for organizational research. Journal of Management Studies, 33, 119-135.

Agustin, C., \& Jagdip, S. (2005). Curvilinear effects of consumer loyalty determinants in relational exchanges. Journal of Marketing Research, 42(February) 96-108.

Anderson, E.W., \& Mittal, V. (2000). Strengthening the satisfaction-profit-chain. Journal of Service Research, 3 (2) $107-20$.

Babakus, E., \& Yavas, U. (2008). Does customer sex influence the relationship between perceived quality and share of wallet? Journal of Business Research, 61, 974-981.

Bagozzi, R.P. (1981). An examination of the validity of two models of attitude. Multivariate Behavioral Research, 16(July) 323-359.

Baker, J., Grewal, D., \& Parasuraman, A. (1994). The influence of store environment on quality inferences and store image. Journal of the Academy of Marketing Science, 22(4) 328-339.

Baker, J., Parasuraman, A., Grewal, D., \& Glenn B. Voss, G. B. (2002). The influence of multiple store environment cues on perceived merchandise value and patronage intentions Journal of Marketing, 66(2) 120-141.

Ball, D., Coelho, P.S., \& Machás, A. (2004). The role of communication and trust in explaining customer loyalty: an extension to the ECSI model. European Journal of Marketing, 38(9) 1272-1293.

Bell, S.J., Auh, S., \& Smalley, K. (2005). Customer relationship dynamics: service quality and customer loyalty in the context of varying levels of customer expertise and switching costs. Journal of the Academy of Marketing Science, 33(2) 169-183.

Bellenger, D.N., Steinberg, E., \& Stanton, W.W. (1976). The congruence of store image and self image. Journal of Retailing, 52(1) 17-32.

Bendall-Lyon, D., \& Powers, T.L. (2002). The impact of gender differences on change in satisfaction over time. Journal of Consumer Marketing, 19(1) 12-23.

Berry, L.L. (1995). Relationship marketing of services: growing interest, emerging perspectives. Journal of the Academy of Marketing Science, 23(4) 236-46.

Boloemer, J., \& de Ruyter, K. (1998). On the relationship between store image, store satisfaction and store loyalty. European Journal of Marketing, 32(5/6) 499-513.

Campbell, C. (1997). Shopping, pleasure, and the sex war. In P. Falk \& C. Campbell (Eds.), The shopping experience? (166-176). London: Sage Publications.

Carmines, E.G., \& Zeller, R.A. (1979). Reliability and validity assessment, Newbury Park, CA: Sage.

Cassel, C., \& Eklof, J.A. (2001). Modelling customer satisfaction and loyalty on aggregate levels: Experience from the ECSI pilot study. Total Quality Management, 12(7-8) 834-841.

Chaudhuri, A., \& Ligas, M. (2009). Consequences of value in retail markets. Journal of Retailing, 85(3) 406-419.

Chin, W.W. (1998a). Issues and opinion on structural equation modeling. MIS Quarterly, 22(1) 7-16.

Chin, W.W. (1998b). The partial least squares approach to structural equation modelling. In Marcoulides, G.A. (Ed.), Modern Methods for Business Research (295-336). Mahwah, NJ: Lawrence Erlbaum Associates.

Chin, W.W., \& Dibbern. J. (2005). An introduction to a permutation based procedure for multi-group PLS analysis: results of tests of differences on simulated data and a cross cultural analysis of the sourcing of information 
system services between Germany and the USA. In V. Esposito Vinzi et al. (Eds.), Handbook of Partial

Least Squares, Concepts, Methods and Applications (171-193). Springer.

Chiu, H.-C. (2002). A study on the cognitive and affective components of service quality. Total Quality Management and Business Excellence, 13(2) 265-274.

Cron, W. L., Gilly, M. C., Graham, J. L., \& Slocum, J. W. (2009). Gender differences in the pricing of professional services: implications for income and customer relationships. Organizational Behavior and Human Decision Processes, 109(1) 93-105.

Cronin, J. J., Jr., Brady, M. K., \& Hult, G.T.M. (2000). Assessing the effects of quality, value, and customer satisfaction on consumer behavioral intentions in service environments. Journal of Retailing, 76(2) 193218.

Cross, S.E., \& Madson, L. (1997). Models of the Self: Self-Construals and Gender. Psychological Bulletin, 122 (1) 5-37.

Dick, A.S., \& Basu, K. (1994). Customer loyalty: toward an integrated conceptual framework. Journal of the Academy of Marketing Science, 22(2) 99-113.

Dimitriades, Z.S. (2006). Customer satisfaction, loyalty and commitment in service organizations: Some evidence from Greece. Management Research News, 29(12) $782-800$.

Dodds,W.B., Kent, B., Monroe, K.B., \& and Grewal, D. (1991). Effects of price, brand, and store information on buyers product evaluations. Journal of Marketing Research, 28 (August) 307-19.

Eagly, A.H. (1987). Sex differences in social behavior: A social-role interpretation. Hillsdale: Lawrence Erlbaum Associates.

Escalas, J.E., \& Bettman, J.R. (2005). Self-construal, reference groups, and brand meaning. Journal of Consumer Research, 32(3) 378-389.

Evanschitzky, H., \& Wunderlich, M. (2006). An examination of moderator effects in the four-stage loyalty model. Journal of Service Research, 8(4) 330-345.

Fischer, M., Völckner, F., \& Sattler, H. (2010). How important are brands? A cross-category, cross-country study. Journal of Marketing Research, 47(5) 823-829.

Fornell, C., \& Larcker, D. (1981), Evaluating structural equation models with unobservable variables and measurement error. Journal of Marketing Research, 18(1) 39-50.

Fornell, C. (1992). A national customer satisfaction barometer: the Swedish experience. Journal of Marketing, 56(1) 6-21.

Fornell, C., Johnson, M.D., Anderson, E.W., Cha, J., \& Bryant, B.E. (1996). The American customer satisfaction index: nature, purpose, and findings, Journal of Marketing, 60(4) 7-18.

Fornell, C. (2002). CFI group. Marketing News, 36(22) 41.

Fornell, C., VanAmburg, D., Morgeson, F., Anderson, E.W., Bryant, B.E., \& Johnson, M.D. (2005). The American customer satisfaction index at ten years. Ann Arbor: University of Michigan.

Fornell, C., Mithas, S., Morgeson, F.V., III, \& Krishnan, M.S. (2006). Customer satisfaction and stock prices: high returns, low risk. Journal of Marketing, 70(1) 3-14.

Frank, B., Enkawa, T., \& Schvaneveldt S.J. (2014). How do the success factors driving repurchase intent differ between male and female customers? Journal of the Academy of Marketing Science, 42, 171-185.

Garbarino, E., \& Strahilevitz, M. (2004). Gender differences in the perceived risk of buying online and the effects of receiving a site recommendation. Journal of Business Research, 57(7) 768-775.

Gelfand, M.J., Smith Major, V., Raver, J.L., Nishii, L.H., \& O’Brien, K. (2006). Negotiating relationally: the dynamics of the relational self in negotiations. Academy of Management Review, 31(2) 427-451.

Grewal, D., Krishnan, R., Baker, J., \& Borin, N. (1998). The effect of store name, brand name and price discounts on consumers' evaluations and purchase intentions. Journal of Retailing, 74(3) 331-352.

Grewal, D., Levy, M., \& Lehmann, D.R. (2004). Retail branding and customer loyalty: an overview. Journal of Retailing, 80, ix-xii.

Grönroos, C. (1995). Relationship marketing: the strategy continuum. Journal of the Academy of Marketing Science, 23(4) 252-54.

Helgesen, Ø., \& Nesset, E. (2010). Gender, store satisfaction and antecedents: a case study of a grocery store. Journal of Consumer Marketing, 27(2) 114-126. 
Helgesen, Ø., Havold, J. I., \& Nesset, E. (2010). Impacts of store and chain images on the "quality-satisfactionloyalty process" in petrol retailing. Journal of Retailing and Consumer Services, 17, 109-118.

Homburg, C., \& Giering, A. (2001). Personal characteristics as moderators of the relationship between customer satisfaction and loyalty - An empirical analysis. Psychology and Marketing, 18(1) 43-66.

Iacobucci, D., \& Ostrom, A. (1993). Gender differences in the impact of core and relational aspects of services on the evaluation of service encounters. Journal of Consumer Psychology, 2(3) 257-286.

Johnson, M.D., Gustafsson, A., Andreassen, T. W., Lervik, L., \& Cha, J. (2001). The evolution and future of national customer satisfaction index models. Journal of Economic Psychology, 22(2) 217-245.

Johnson, M.D., Herrmann, A., \& Huber, F. (2006). The evolution of loyalty intentions. Journal of Marketing, 70(2) $122-132$.

Kim, H.-S., \& Yoon, C.-H. (2004). Determinants of subscriber churn and customer loyalty in the Korean mobile telephony market. Telecommunications Policy, 28(9-10) 751-765

Kivetz, R., \& Simonson, I. (2002). Earning the right to indulge: effort as a determinant of customer preferences toward frequency program rewards. Journal of Marketing Research, 39 (May) 155-70.

Kivetz, R., \& Simonson, I. (2003). The idiosyncratic fit heuristic: effort advantage as a determinant of consumer response to loyalty programs. Journal of Marketing Research, 40 (November) 454-67.

Krishnan, B.C., Biswas, A., \& Netemeyer, R.G .(2006).Semantic cues in reference price advertisements: the moderating role of cue concreteness. Journal of Retailing, 82(2) 95-104.

Lawrence, J.W., Fauerbach, J.A., \& Thombs, B.D. (2006). A test of the moderating effect of importance of appearance in the relationship between perceived scar severity and body-esteem among adult burn survivors. Body Image, 3(2) 101-111.

Lewis, K.M. (2000). When leaders display emotion: How followers respond to negative emotional expression of male and female leaders. Journal of Organizational Behavior, 21, 221-234.

Martenson, R. (2007). Corporate brand image, satisfaction and store loyalty - A study of the store as a brand, store brands and manufacturer brands. International Journal of Retail \& Distribution Management, 35(7) 544555.

Maxham, J.G., \& Netemeyer, R.G. (2002). A longitudinal study of complaining customers' evaluations of multiple service failures and recovery efforts. Journal of Marketing, 66(4) 57-71.

Mazursky, D., \& Jacoby, J. (1986). Exploring the development of store image. Journal of Retailing, 62(2) 145-165.

McColl-Kennedy, J. R., Daus, C. S., \& Sparks, B. A. (2003). The role of gender in reactions to service failure and recovery. Journal of Service Research, 6(1) 66-82.

McGoldrick, P. J., \& Andre, E. (1997). Consumer misbehaviour: promiscuity or loyalty in grocery shopping. Journal of Retailing and Consumer Services, 4(2), 73-81.

Melnyk, V., van Osselaer, S.M.J., \& Bijmolt, T.H.A. (2009). Are women more loyal customers than men? Gender differences in loyalty to firms and individual service providers. Journal of Marketing, 73(4) 82-96.

Meyers-Levy, J. (1988). The influence of sex roles on judgment. Journal of Consumer Research, 14(4) 522-530.

Mittal, V., Ross, W.T., \& Baldasare P.M. (1998). The asymmetric impact of negative and positive attribute-level performance on overall satisfaction and repurchase intentions. Journal of Marketing, 62(1) 33-47.

Mittal, V., \& Kamakura, W.A. (2001). Satisfaction, repurchase intent, and repurchase behavior: investigating the moderating effect of customer characteristics. Journal of Marketing Research, 38(1) 131-142.

Morgan, R.M., \& Shelby, H.D (1994). The commitment-trust theory of relationship marketing. Journal of Marketing, 58(July) 20-39.

Moutinho, L., Davies, F., \& Curry, B. (1996). The impact of gender on car buyer satisfaction and loyalty. Journal of Consumer Services and Retailing, 3(3) 135-144.

Ndubisi, N. O. (2006). Effect of gender on customer loyalty: a relationship marketing approach. Marketing Intelligence and Planning, 24(1) 48-61.

Ngobo, P.V. (2004). Drivers of customers'cross-buying intentions. European Journal of Marketing, 38(9/10) 11291157.

Noble, S.M., Griffith, D.A., \& Adjei, M.T. (2006). Drivers of local merchant loyalty: understanding the influence of gender and shopping motives. Journal of Retailing, 82(3) 177-188.

Oliver, R.L. (1981). Measurement and evaluation of satisfaction processes in retail settings. Journal of Retailing, 57(3) 25-48. 
Oliver, R.L. (1999). Whence consumer loyalty? Journal of Marketing, 63 (Special Issue) 33-44.

Pan, Y., \& Zinkhan G.M. (2006). Determinants of retail patronage: A meta-analytical prospective. Journal of Retailing, 83(1) 229-243.

Putrevu, S. (2001). Exploring the origins and information processing differences between men and women: implications for advertisers. Academy of Marketing Science Review, 10, 1-15.

Reichheld, F.F. (1993). Loyalty-based management. Harvard Business Review, 71(2) 64-73.

Reichheld, F.F., Markey, R.G Jr., \& Hopton. C. (2000). E-customer loyalty - applying the traditional rules of business for online success. European Business Journal, 12(4) 173-179.

Rust, R.T., Zahorik, A.J., \& Keiningham, T.L. (1995). Return on quality (ROQ): making service quality financially accountable. Journal of Marketing, 59 (April) 58-70.

Schwartz, S.H., \& Rubel-Lifschitz, T. (2005). Sex differences in value priorities: cross-cultural and multimethod studies. Journal of Personality and Social Psychology, 89(6) 1010-1028.

Schwartz, S.H., \& Rubel-Lifschitz, T. (2009). Cross-national variation in the size of sex differences in values: effects of gender equality. Journal of Personality and Social Psychology, 97(1) 171-185.

Shemwell, D.J., Jr., \& Cronin, J.J., Jr. (1995). Trust and commitment in customer/service-provider relationships: an analysis of differences across service types and between sexes. Journal of Customer Service in Marketing and Management, 1(2) 65-75.

Sirgy, M.J. (1985). A path analytic model of store loyalty involving self-concept, store image, geographic loyalty, and socioeconomic status. Journal of the Academy of Marketing Science, 13(3) 265-292.

Stan, V., \& Caemmerer, B. (2015). The development and management of organizational partner satisfaction. Journal of Applied Business Research, 31(1), 47-60.

Stan, V. (2014). Antecedents of customer loyalty in the retailing sector: the impact of switching costs. Journal of Applied Business Research, 31(2) 371-382.

Stearns, P.N. (1992). Gender and emotion: A twentieth century transition. Social Perspectives on Emotion, 1, 127160.

Stuhlmacher, A.F., \& Walters, A.E. (1999). Gender differences in negotiation outcome: a meta-analysis. Personnel Psychology, 52(3) 653-677.

Sweeney, J.C., \& Soutar, G.N. (2001). Consumer perceived value: the development of a multiple item scale. Journal of Retailing, 77(2) 203-220.

Tenenhaus, M., Vinzi, V.E., Chatelin, Y.-M., \& Lauro, C. (2005). PLS path modeling. Computational Statistics \& Data Analysis, 48(1), 159-205.

Tian, K.T., Bearden, W.O., \& Hunter, G.L. (2001). Consumers' need for uniqueness: scale development and validation. Journal of Consumer Research, 28(1) 50-66.

Türkyılmaz, A., \& Özkan, C. (2007). Development of a customer satisfaction index model: an application to the Turkish mobile phone sector. Industrial Management \& Data Systems, 107(5) 672-687.

Van Heerde, H.J., \& Bijmolt, T.H. A. (2005). Decomposing the promotional revenue bump for loyalty program members versus nonmembers. Journal of Marketing Research, 42 (November) 443-57.

Veloutsou, C., Gilbert, R.G., Moutinho, L.A., \& Good, M.M. (2005). Measuring transaction specific satisfaction in services. European Journal of Marketing, 39(5-6) 606-28.

Yuping, L., \& Yang, R. (2009). Competing loyalty programs: impact of market saturation, market share, and category expandability. Journal of Marketing, 73 (January) 109-121.

Wold, H. (1966). Estimation of principal components and related models by iterative least squares. In

P.R. Krishnaiah (Ed.), Multivariate Analysis (391-420). New York: Academic Press.

Zeithaml, V.A. (1988). Consumer perceptions of price, quality, and value: a means-end model and synthesis of evidence. Journal of Marketing, 52 (July) 2-22. 